\title{
Does the presence of governance structure affect small and medium-sized enterprise performance? Evidence from an emerging market
}

\author{
Daniel Okofo-Darteh, Emmanuel Selase Asamoah
}

\begin{abstract}
A B S T R A C T
Objective: The objective of the article is to determine the effect of governance structure components (audit committee presence, board size adequacy, and board leadership) on SMEs' performance and the moderating effect of chief executive officer (CEO) tenure on the influence of governance structure on SMEs' performance in Ghanaian context.

Research Design \& Methods: We sampled 145 respondents from selected SMEs in the Ghanaian manufacturing, telecommunication, and financial sectors for the study. All selected participants completed questionnaires on governance structure and shared their informed perception of the enterprises' performance. The data gathered were analysed using multiple regression analysis and Hayes' process macro.
\end{abstract}

Findings: The results indicated that board leadership, the presence of an audit committee, and board size adequacy do not significantly influence SMEs' performance. The results further revealed that CEO tenure is a significant negative moderator to the influence of the governance structure on SMEs' performance.

Implications \& Recommendations: Future studies must focus on how SMEs in Ghana can put CEOs and board succession plans in place so as to ensure creativity/innovation.

Contribution \& Value Added: This study contributes to the body of knowledge relating to the governance structure's influence on various indicators of business performance of SMEs in Ghana. Therefore, this study sought to assess the contribution of corporate governance structures to the performance of SMEs in Ghana. This would help SMEs to know which aspects of their governance structure should be strengthened to effectively contribute to their success.
Article type: research article
Keywords:
governance structure; board size adequacy; board leadership; audit committee; enterprise performance

JEL codes:

Received: 27 January 2020

Revised: 23 June 2020

Accepted: 8 July 2020

\section{Suggested citation:}

Okofo-Darteh, D. \& Asamoah, E.S. (2020). Does the presence of governance structure affect small and medium-sized enterprise performance? Evidence from an emerging market. Entrepreneurial Business and Economics Review, 8(3), 117-133. https://doi.org/10.15678/EBER.2020.080307 


\section{INTRODUCTION}

Small and medium-sized enterprises (SMEs) are considered critical to economic growth and equitable development in developing economies (Agwu \& Emeti, 2014). They are usually regarded as efficient, creative, and fruitful job creators, the seeds of future big industry giants, and the fuel of national economy (Abor \& Quartey, 2010). As important as SMEs are to various economies, it is important to ensure their effective management and good corporate governance. The major aim is long-term shareholder value, while taking into account the interests of other stakeholders (Abor \& Adjasi, 2007). Abor and Adjasi (2007) opined that - since corporate governance regulates the internal affairs of large scale companies - it may also improve SME performance, if regulators make it a mandatory requirement. Moreover, the majority of SMEs in Ghana find themselves in the owner/chief executive officer (CEO)/manager situation, in which they take it upon themselves to shoulder all major decisions (Abor \& Adjasi, 2007).

This appears to be a problem for the SME sector in Ghana because most of such entrepreneurs usually possess limited formal education, access to cutting-edge technologies, and market information; thus, scholars believe these entrepreneurs to be characterised by the lack or inadequate presence of proper governance systems (Abor \& Biekpe, 2007). Most efforts to help remedy this phenomenon by researchers appear to be mainly limited to studies on SMEs in developed economies (Bennett \& Robson, 2004) to the near neglect of emerging markets in Africa and specifically Ghana.

The focus of corporate governance studies in emerging markets has largely ignored SMEs. The few existing studies on SMEs' governance in Ghana justifiably employ objective measures. However, the present study appears to be one of the very few studies - if not the sole study - to use subjective measures. The novelty of our study lies in the fact that it departs from usual corporate governance studies on large corporations to bring to light what pertains in the SME circles in Ghana by using subjective measures and determining the moderating influence of CEO tenure on the governance structure-enterprise performance link. While it is imperative to examine corporate governance in the SME sector in the context of an emerging economy such as Ghana, the question of whether the presence of governance structures in SMEs contributes to their performance appears to have no recent empirical elaboration with subjective measures.

Therefore, the objectives of our study are to discover the effect of governance structure components on the performance of SMEs in Accra and to determine the moderation effect of CEO tenure on the relationship between governance structure and enterprise performance in SMEs. The literature review presents empirical studies on the relationship between components of governance structure of this study's interest - board size adequacy, the presence of an audit committee, board leadership, and CEO tenure - and performance.

\section{LITERATURE REVIEW AND THEORY DEVELOPMENT}

\section{Ghanaian Business Context}

The business sector of Ghana is thriving and characterised by small, medium-sized, and large enterprises. The main sectors include: agriculture which contributes $18.3 \%$ of GDP, and employs about $34 \%$ of the country's workforce; manufacturing accounts for about $31.5 \%$ of 
GDP, which is dominated by mining, lumbering, light manufacturing, aluminium smelting, food processing, cement production, small commercial ship building, and petroleum; whereas the largest component of the economy is the service sector that comprises about $43 \%$ of GDP, employing about $48 \%$ of the working population (NORDEA, 2020). Altogether, SMEs in the country contribute $85 \%$ of employment in the manufacturing sector, represent about $70 \%$ of GDP and account for about $85 \%$ of general business in the country. Policymakers, development practitioners, and community leaders continue to develop policies and strategies to improve the sector (Okofo-Darteh, Amartei-Kwei, \& Boahen, 2020).

\section{What Is an SME in Ghana?}

An SME is usually defined using the number of employees of the enterprise or the value of the enterprise's fixed assets (Abor \& Quartey, 2010). The Ghana Statistical Services (GSS), the Ghana Enterprise Development Commission (GEDC), and the National Board for Small Scale Industries (NBSSI) consider either the number of employees or value of fixed assets or both as criteria for their unique categorisation of enterprises, respectively.

However, the current study favours the definition by the Regional Project on Enterprise Development Ghana, which classifies enterprises into: (i) micro enterprise, with less than five employees; (ii) small enterprise, with five to 29 employees; (iii) medium enterprise, with 30-99 employees; (iv) large enterprise, with a 100 and more employees. Therefore, for the purpose of this study, SMEs are enterprises that employ from five to 99 employees in Ghana. While most SMEs in Ghana are family-controlled businesses, others are listed on the stock exchange and tend to have limited control of the business by a family. The focus of this study is generally on small and medium-sized enterprises in Ghana: listed and unlisted.

\section{Corporate Governance}

The OECD (2004) defines corporate governance as a set of relationships between a company's board, its shareholders, and other stakeholders. Cadbury (1992) also defines corporate governance as a whole system of controls, both financial and other, with which a company is directed and controlled. Both definitions reveal the fact that corporate governance represents the conscience of an enterprise in all its dealings. Therefore, the study considers both definitions. Other theories also help build on the concept by propounding theories that explain the corporate governance issue, namely the agency theory, the stewardship theory, the resources dependence theory, and the stakeholder theory.

The agency theory necessitates a contract under which business owners (principal) employ someone as a CEO and others as board members (agents) to run the business in the interest of the owners. Instead, the stewardship theory opines that the main aspiration of management is to maximise the enterprise's performance by being a good custodian of corporate assets (Muth \& Donaldson, 1998). The resource dependence theory by Pfeffer (1973) and Pfeffer and Salancik (1978) emphasises that board directors should be non-executives who have valuable social capital and connections to enhance the enterprise's ability to acquire resources from various sources. According to this theory, board directors usually become the conduit for resource acquisition mainly through their social and professional networks (Johannisson \& Huse, 2000). The stakeholder theory expresses the need for enterprises to consider the interests of various other stakeholder groups - including employees, customers, suppliers, the local community - in addition to interests of investors (Freeman, 1984; Gibson, 2000). This will result in the enterprise's ability to build consensus among all 
critical stakeholders. What applies better in the case of family-owned SMEs employing nonfamily members to the board are the stewardship and stakeholder theories.

\section{Corporate Governance through the Prism of New Institutional Economics}

New institutional economics (NIE) focuses on coordination processes that lead to particular decisions about resource allocation rather than on results of resource allocation. Klepczarek (2017) believes that the new institutional economics concept relies on institutions, governance structures, and individuals' interaction in the organization, which determines the performance of the organization and the economy. Researchers currently agree with Sonmez and Yildirim (2015) that corporate governance is usually concerned with issues of shareholders' value maximization (the agency theory) and the role of stakeholders in the management system of enterprises (the stakeholder theory). They also believe that agency and stakeholder theory along with all other institution-related corporate governance theories are partial paradigms or perspectives that always go together just as the NIE perspective suggests; even in the case of SMEs in Ghana that practice corporate governance.

\section{Why Ghanaian SMEs May Find Corporate Governance Important?}

SMEs in Ghana are increasingly embracing the concept of good corporate governance as it leads to sustainable business growth (Kyereboah-Coleman \& Amidu, 2008). There have also been several calls from professional institutions concerning the need for SMEs to have a good governance framework in place. First is the continual advice by Ghana's Trade and Industry Ministry to SMEs to adopt governing boards and proper management systems to provide enterprises with strategic direction for their operation. Second, Ghana's Companies Act of 2019 (Act 992) stipulates that all companies registered under the law, regardless of their size or public interest level, must be audited by certified auditors and must file audited financial statements with the Registrar General. The Act also stipulates the need to appoint directors, and it defines the role of board chairs. Now, since most SMEs register as companies, they are enjoined by law to comply. Therefore, proper compliance with law implies the need for good corporate governance practices, and governing boards to oversee the compliance internally. Moreover, the introduction of the SME capital market - the Ghana Alternative Exchange (GAX), which is a category of listing on the exchange to SMEs - has also implicitly influenced most SMEs in Ghana to establish governing boards to be able to list on the exchange when thinking of scaling-up their businesses. Finally, while the SMEs in Ghana may not really want to institute a board, they may still find it necessary out of sheer mimicry, since they want to appear like the larger more successful companies that profess to have a board and tout their operations to be guided by board decisions.

\section{Components of Governance Structure}

The following provides an analysis of the empirical literature on the components of governance structures within enterprises.

\section{Board Size Adequacy}

There are two distinct schools of thought on the adequacy of size of the boards. The first believes that a smaller board size - while competent and closely-knit - would contribute to the success of an enterprise (Mayur \& Saravanan, 2017) more than a large board size (Coles, Daniel, \& Naveen, 2008). Other studies indicate that a large board will support and 
advise enterprise management more effectively in a complex business environment (Bertrand, Black, Jensen, \& Lleras-Muney, 2019). Kumar and Singh (2013) opine that a large board size will gather much more information for enterprise performance. Empirical studies in Ghana expose inconclusive relationships between the adequacy of board size and performance. A study by Ansong (2015) in Ghana reveals that there is a significant positive relationship between board size adequacy and enterprise performance. This is corroborated by Abor and Biekpe (2007) who find that there is positive association between board size and performance. Kyereboah-Coleman and Amidu (2008) find instead a negative correlation between board size and performance. Their argument is that large boards are less effective and easier for the CEO to control as opposed to smaller boards whose size reduces the possibility of free-riding by individual directors, which increases the effectiveness of smaller boards' decision-making processes. However, a study by Topak (2011) reveals that that board size adequacy does not have a significant influence on enterprise performance. The current study hypothesises that:

H1: Board size adequacy will have a significant positive influence on enterprise performance.

\section{Audit Committee}

Accounting irregularities are rife in corporate organizations, which results in compliance issues; therefore, audit committees should be established in organizations (KyereboahColeman, 2007). This helps to make such committees independent. Thus, Kyereboah-Coleman (2007) advance that a wholly independent audit committee should consist solely of Non-Executive Directors and non-affiliates of the company, such as the enterprise's previous directors. Omer, Shelley, and Tice (2019) reveal that earning reports improve once audit committees are established, since its establishment engenders transparency and compliance. It is expected that the work of audit committees helps to achieve enterprise performance (Badolato, Donelson, \& Ege, 2014). A study by Kyereboah-Coleman and Amidu (2008) in Ghana reveals that the presence of audit committees to oversee day-today financial commitments of enterprises and make prudent use of funds enhances performance. Dzigba (2015) reveals that, among SMEs in Ghana, audit committees were the most relevant among all other subcommittees to financial performance and access to credit. Ojeka, lyoha, and Obigbemi (2014) in Nigeria also report a significant positive relationship between an audit committee and financial performance, because of the former's financial expertise. Apparently, SMEs with audit committees are successful according to previous empirical studies. The current study hypothesises that:

H2: The presence of audit committees will have a significant positive influence on enterprise performance.

\section{Board Leadership Structure}

CEO and chairperson positions may be held by the same person, which may likely pose serious problems (Emile, Ragab, \& Kyaw, 2014). According to Ponnu (2008), some enterprises employ a combined leadership structure, in which the CEO doubles as board chair, while other employ a separated structure, which clearly distinguishes the positions of CEO from board chairmanship. Most researchers favour the separated structure because it ensures the balance of power of both positions in addition to avoiding a conflict of 
interest. Ponnu (2008) and Emile et al. (2014) further assert that it is also to promote fair judgment. Many studies identify the implications of CEO duality. Enterprises involved in earnings manipulations usually have a CEO doubling as the board chair (Ponnu, 2008). To this, Ponnu (2008) furthers that in all types of enterprises, when the combined leadership structure is employed, such a situation leads to the board being compromised so that its opinions and recommendations are dogmatically the same as that of the CEO, despite the presence of independent directors.

Abor and Biekpe (2007) report that there is a positive relationship between CEO duality and enterprise performance. This suggests that in SMEs where an individual combines both CEO and board chairman roles (one-tier board leadership structure), enterprise performance is better than those with two individuals performing such roles (twotier board leadership structure). Conversely, Sanda, Mukaila, and Garba (2003) find in the Nigerian context a positive relationship between enterprise performance and the board leadership structure where the functions of the CEO and Chairman are separated. Instead, Rashid (2009) shows on the example of Bangladesh that board leadership structure does not influence enterprise performance. Clearly, there is inconclusive empirical evidence of the influence of board leadership structure on enterprise performance. Nevertheless, the current study hypothesises that:

H3: Board leadership structure will have a significant positive influence on enterprise performance.

\section{Enterprise Performance}

One of the most appropriate objective measures for enterprise performance for this study is Tobin's $Q$, which is probably the most frequently used valuation measure in empirical corporate finance. Tobin's $Q$ is the ratio of market value to the replacement value of an enterprise's assets. As an approximation for measurement, the market value of assets is normally computed as market value of equity plus book value of assets, minus book value of equity (Kyereboah-Coleman \& Biekpe, 2008). The result is then divided by the book value of assets to obtain the Tobin's $Q$, which indicates that management has done well in its investment decisions. However, the researchers were constrained, since the enterprises were protective of the necessary information needed to calculate the Tobin's Q. However, subjective performance measures have proven to also be reliable for measuring enterprise performance (Venkatraman \& Ramanujam, 1987). Subjective performance measures increase the response rate in which objective data are neither available nor are there respondents willing or able to reveal the information. Enterprise performance in this study is defined as the composite index of perceptions of profitability, sales, market share, and productivity.

\section{Moderating Variables}

Moderators are variables that seek to affect the relationship between dependent and independent variables. The present study tests CEO tenure as a moderator.

\section{CEO Tenure}

CEO tenure in this study is expressed as the number of years a CEO has held the position. Rashid, Islam, and Anderson (2008) state that moderating variables play an important role in the relationship between independent and dependent variables. Merika, Triantafyllou, 
Kalogeropoulou, and Kalokairinos (2016), Galoji, Ahmed, and Johari, (2013), Allgood and Farrell (2000) and Luo, Kanuri, and Andrews (2013) find that CEO tenure positively influences performance, and the longer a CEO serves, the more enterprise performance improves. This is because it affords the CEO's the opportunity to witness the results of their decisions (Kyereboah \& Coleman, 2007).

Nonetheless, we should note that CEO tenure may also negatively affect enterprise performance. The leader life cycle theory proposed by Hambrick and Fukutomi (1991) asserts that performance slumps as CEO interest in tasks gradually decrease, usually after six years (Giambatista, 2004). Therefore, in our study we tested CEO tenure as a moderating variable in the SME context. It advances the argument that CEO tenure constitutes another important governance mechanism (Kyereboah-Coleman, 2007). The present study aims to determine the effect of governance structures' components on the performance of SMEs and the moderating effect of CEO tenure on governance structures and SMEs performance. Thus, we formulated following hypothesis:

H4: CEO tenure will have a significant positive moderation influence on the relationship between governance structure and enterprise performance.

\section{MATERIAL AND METHODS}

\section{Population and sample}

The population of interest for this study included all SMEs in Ghana. Information from the Association of Ghana Industries (AGI) suggests an estimated registered population of about 1500 SMEs nationwide. The estimated population of registered SMEs in Accra was about 800 registered SMEs. Purposive-snowball sampling technique was employed. Purposive sampling technique was employed for choosing enterprises, because the study focused on SMEs that made efforts to establish a governance board and relevant committees. These should have been in operation for at least five consecutive years, so that their CEOs would have completed the "honeymoon period" defined as the first three years of office (Limbach, Schmid, \& Scholz, 2015). Such enterprises would have a great deal of experience with sustained governance structures. For the respondents of the study, we employed the snowball sampling technique.

The sampling frame for the study comprised senior-level employees who interact with the governance structure of enterprises or companies. The sample size was determined using the sample size formula by Tabachnik and Fidell (2007), which stipulates that for an appropriate sample size in studies that employ multiple regression, the minimum sample size $(N)$ should be $(N>50+8 M)$ in which $M$ is the total number of independent variables. As there are three independent variables in the study, the minimum sample size required for this study was 74 ; i.e. $50+8(3)=74$. Therefore, the sample size of 145 respondents each representing 145 enterprises more than satisfies the acceptable sample size for the present study.

\section{Instrumentation}

The study employs the following measuring instruments: 


\section{Governance Self-Assessment Test}

This instrument was originally developed by Gill, Flynn, and Reissing (2005) and covers some governance structure essentials that boards ought to display for effective governance. Therefore, the instrument was used to measure perceptions of variables such as the presence of audit committee, board size adequacy, and board leadership. Responses to these statements were measured on a five-point Likert scale. Hence, the respective variables were computed as the mean of aggregate responses to question items relating to each governance structure component. Governance structure was also operationalised as a mean scores index of computed governance structure components.

\section{Enterprise Performance Survey}

In a single statement, the researchers subjectively measured enterprise performance with respect to profitability, sales, market share, and productivity. Responses to these statements were measured on a five-point Likert scale. Therefore, enterprise performance was computed as a mean of the aggregate of responses on the enterprise performance survey. Therefore, enterprise performance in this study is defined as the composite index of perceptions of profitability, sales, market share, and productivity.

\section{Reliability and Validity}

The reliability of the Governance Self-Assessment Test was tested using a test-retest procedure. The researchers repeated measurements of the same respondent by using the same questionnaire within an interval of seven days. The researchers repeated the measurement of the same tool using the same questionnaire under similar conditions. Using the Statistical Package for Social Sciences (SPSS) version 21, the reliability of the tools was calculated to ensure a Cronbach's alpha $(\alpha)$ at or above 0.6 , which is the acceptable value. If the results are similar then the questionnaire has high reliability. The value of Cronbach's alpha coefficient was expected to be 1.0, which indicates the high reliability of the instrument. Nunnally and Bernstein (1994) state that, a Cronbach's alpha value equal to or greater than 0.70 is considered satisfactory. Reliability estimates between 0.60 and 0.70 are acceptable; whereas a Cronbach's alpha below 0.60 is usually regarded as unacceptably low. The final reliability tests obtained were Governance Structure, $\alpha=0.853$, and enterprise performance, $\alpha=0.870$.

\section{The Assumption of Normality Test}

A normality test was conducted for all variables, and it satisfied the requirement that data collected must be normally distributed. The inferential statistic information obtained is that the $p$ values for variables ranged from 0.081 to 0.296 , according to the Shapiro-Wilk normality test. The normality test showed that all values were significant as the data met the threshold of 0.05 .

\section{RESULTS AND DISCUSSION}

The following section presents the results of data analysis and findings. The analyses are presented per each research objective. 


\section{Enterprises Demographics}

Table 1 also shows the demographic distribution of the SMEs.

Table 1. Enterprises' Demographic Description

\begin{tabular}{|l|l|c|c|}
\hline \multicolumn{1}{|c|}{ Variables } & \multicolumn{1}{|c|}{ Items } & Frequency & Percentage (\%) \\
\hline \multirow{5}{*}{ Enterprise Age } & 5 years & 18 & 12.4 \\
\cline { 2 - 4 } & 6 years & 30 & 20.7 \\
\cline { 2 - 4 } & 7 years & 29 & 20.0 \\
\cline { 2 - 4 } & 8 years and more & 68 & 46.9 \\
\hline \multirow{2}{*}{ Enterprise size } & $5-29$ employees & 98 & 67.6 \\
\cline { 2 - 4 } & $30-99$ employees & 47 & 32.4 \\
\hline \multirow{2}{*}{ CEO Duality } & Yes & 93 & 64.1 \\
\cline { 2 - 4 } & No & 52 & 35.9 \\
\hline \multirow{3}{*}{ CEO Tenure } & 3 years & 22 & 15.2 \\
\cline { 2 - 4 } & 4 years & 45 & 31.0 \\
\cline { 2 - 4 } & 5 years and more & 78 & 53.8 \\
\hline
\end{tabular}

Source: own elaboration of research results $(n=145)$.

Out of the 145 SMEs, 18 (12.4\% of all studied SMEs) operated for at least five years, $30(20.7 \%)$ were in business for six years, 29 (20\%) for seven years, and $68(46.9 \%)$ for eight years and more. Ninety-eight (98) enterprises (67.6\%) were small-sized businesses ranging from five to 29 employees, while 47 enterprises (32.4\%) were medium-sized businesses with 30 to 99 employees. The majority of CEOs (78; $53.8 \%$ of all studied CEOs) controlled their enterprises for five years and more, followed by 45 (31\%) CEOs who held the position for four years. Twenty-two (22) CEOs (15.2\%) held their posts for three years. The question of CEO duality required a 'Yes' or 'No' answer. A 'Yes' answer is interpreted to mean that the CEO (owner) is also the board chair. The 'No' answer means the opposite. Therefore, 93 CEOs (64.1\% of all studied CEOs) acted as board chairs, whereas 52 CEOs did not double as board chairs, which meant that different individuals lead their boards.

\section{First Research Objective}

The first research objective sought to determine the effect of governance structure components - board size adequacy, the presence of an audit committee, board leadership on enterprise performance. Table 2 provides the coefficient matrix of governance structure and performance of small and medium-sized enterprises.

The study found that board size adequacy did not significantly contribute to enterprise performance $(\beta=-0.063, p=0.460)$. Hence, we reject the hypothesis $\mathrm{H}_{1}$ "Board size adequacy will have a significant positive influence on enterprise performance," and we accept the null hypothesis. This is contrary to findings by Ansong (2015) and Abor and Biekpe (2007) who revealed that the relationship of board size to enterprise performance is direct, statistically significant, and positive. The finding of Kyereboah-Coleman and Amidu (2008) that there is a negative relationship was also not confirmed. However, Topak (2011) corroborates the findings of the present study, as he found that board size does not have a significant influence on enterprise performance. This means that the size of the board 
does not play any important role in the performance of enterprises. This is quite close to saying that boards in Ghanaian SMEs are probably just for show.

Table 2. Regression of governance structure components on enterprise performance

\begin{tabular}{|l|c|c|c|c|c|c|c|}
\hline \multicolumn{1}{|c|}{ Variables } & $\begin{array}{c}\text { Unstandardised } \\
\text { Coefficients }\end{array}$ & \multicolumn{2}{c|}{$\begin{array}{c}\text { Standardised } \\
\text { Coefficients }\end{array}$} & \multicolumn{2}{|c|}{ x } & \multicolumn{2}{c|}{$\begin{array}{c}\text { Collinearity } \\
\text { Statistics }\end{array}$} \\
\hline \multicolumn{1}{|c|}{ Model } & B & se & Beta & $\mathbf{t}$ & $\mathbf{p}$ & Tolerance & VIF \\
\hline 1 (Constant) & 14.150 & 2.227 & $\mathrm{X}$ & 6.353 & 0.000 & $\mathrm{X}$ & $\mathrm{X}$ \\
\hline BSizeAd & -0.063 & 0.084 & -0.063 & -0.740 & 0.460 & 0.985 & 1.015 \\
\hline Audit & 0.003 & 0.101 & 0.002 & 0.027 & 0.979 & 0.866 & 1.154 \\
\hline BLead & 0.023 & 0.088 & 0.023 & 0.257 & 0.789 & 0.878 & 1.139 \\
\hline
\end{tabular}

Note: dependent variable is enterprise performance.

$\mathrm{B}$ - unstandardised beta, se - standard error, $\mathrm{t}$ - $\mathrm{t}$-test value, $\mathrm{p}$ - significance value, VIF - Variance Inflation Factor.

Source: own elaboration based on research results $(n=145)$.

Our study also found that audit committees do not contribute significantly to enterprise performance $(\beta=0.003, p=0.979)$. Hence, we reject the hypothesis $\mathrm{H}_{2}$ "The presence of audit committees will have a significant positive influence on enterprise performance" and accept the null hypothesis. These committees are established to ensure compliance with requirements of regulatory bodies, ensure internal auditing and help to minimise unnecessary expenditure within organisations. In line with the agency theory, an audit committee functions as an additional control mechanism that ensures that shareholders' interests are secured (Ahmed \& Gabor, 2012). The frequency of audit committee meetings is supposed to enable them to perform their functions effectively by concurrently safeguarding the interest of shareholders. The non-influence of committees on performance may result from inadequate and ineffective meetings. Another reason for that may stem from CEOs' dual roles, hence domination of their whims over the committees.

Furthermore, board leadership $(\beta=0.023, p=0.789)$ failing to influence enterprise performance necessitated our rejection of the hypothesis $\mathrm{H}_{3}$ "Board leadership structure will have a significant positive influence on enterprise performance" and accept the null hypothesis. The board leadership literature reveals mixed findings in regard to the extent of CEOs' effectiveness doubling as board chairmen; whereas some observe positive influence (Harjoto \& Hoje, 2008), others notice negative influence (see Schmid \& Zimmermann, 2005) or show indifferent findings (Elsayed, 2007; Rahman \& Haniffa, 2005). According to Lokuwaduge (2011), agency theory and stewardship theory address the board leadership structure.

\section{Second Research Objective}

The second research objective focused on determining the moderation effect of CEO tenure on the relationship between governance structure (independent variable) and enterprise performance in small and medium scale enterprises. The results of coefficients table for CEO tenure moderation are provided in the table below.

According to the moderation analysis, CEO tenure significantly influenced performance, as $\beta=0.62$, $\mathrm{t}(141)=3.74, \mathrm{p}=0.0003$. However, governance structure failed to significantly contribute to enterprise performance, as $\beta=0.019, \mathrm{t}(141)=0.42, \mathrm{p}=0.68$. Nonetheless, when the interaction term was added to the model, it significantly contributed to the overall enterprise performance model, as shows the significant interaction $B=$ 
$-0.13, t(141)=-2.23, p=0.03$. The findings revealed that CEO tenure is a significant negative moderator of the relationship between governance structure and enterprise performance. The overall model also proved significant $F(3,141)=5.3887, p=0.0015, R^{2}=0.103$. Therefore, we reject the hypothesis $\mathrm{H}_{4}$ that "CEO tenure will have a significant positive moderation influence on the relationship between the governance structure and enterprise performance" and accept the null hypothesis.

Table 3. The regression of CEO tenure moderation effects on governance structure-enterprise performance link

\begin{tabular}{|l|c|c|c|c|}
\hline \multicolumn{1}{|c|}{ Variables } & B & se & t & $\boldsymbol{p}$ \\
\hline constant & 13.7103 & 0.1530 & 89.5963 & 0.0000 \\
\hline CEO Tenure & 0.6157 & 0.1647 & 3.7393 & 0.0003 \\
\hline Governance Structure & 0.0191 & 0.0460 & 0.4155 & 0.6784 \\
\hline Interaction & -0.1282 & 0.0576 & -2.2268 & 0.0275 \\
\hline
\end{tabular}

Interactions: governance structure and CEO tenure.

$\mathrm{B}$ - unstandardised beta, se - standard error, $\mathrm{t}-\mathrm{t}$-test value, $\mathrm{p}$ - significance value.

Source: own elaboration of research results $(n=145)$.

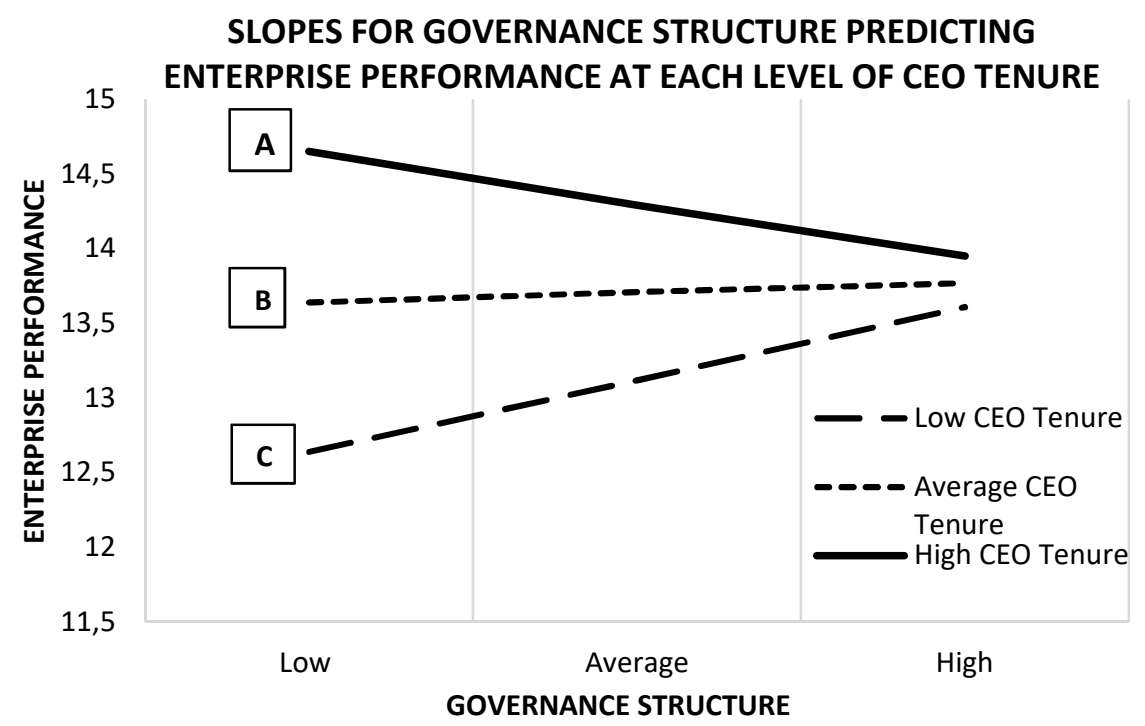

Figure 1. Slopes for governance structure predicting enterprise performance at each level of CEO tenure

Source: own elaboration based on the 2019 study $(n=145)$.

Figure 1 shows that CEO tenure is a significant negative moderator of the relationship between governance structure and enterprise performance. The horizontal $(x)$ axis represents three (3) levels of governance structure, whereas the vertical (y) axis - labelled enterprise performance - depicts the various mean levels of enterprise performance when 
the low, average, or high levels of the moderator (CEO tenure) is introduced into the relationship between governance structure and enterprise performance. From Figure 1, we read that the simple slope $C$ for enterprise performance at one standard deviation (1 $S D$ ) below the mean was 12.64 , the unstandardised simple slope B for enterprise performance at the mean level was 13.64, and the unstandardised simple slope $A$ for enterprise performance at $1 S D$ above the mean of CEO tenure was 14.65. This slope $A$ is what depicts a significant negative moderation effect by CEO tenure.

Therefore, at low CEO tenure - when the CEO holds the position for a few years - governance structure can predict increasing enterprise performance depicted by the dashed simple slope C. At average CEO tenure - when the CEO stays at post for a reasonable period of time - governance structure predicts insignificant change in levels of enterprise performance depicted by the dotted simple slope B. At high CEO tenure - when the CEO stays at post for an extended period of time - governance structure predicts decreasing enterprise performance, as depicted by the inverse downward movement of the solid simple slope $A$ from left to right. We may deduce from the findings that CEO tenure seems either too short or too long so that its moderation effect on the governance structure-performance link is significantly negative. According to Limbach et al. (2015), very short or long CEO tenures are linked to performance inefficiencies. Tornyeva and Wereko (2012) explain that CEOs may either take strategic decisions that are short term, medium-term, or long term.

Granting long tenures to CEOs may assure CEOs job security and influence their investment decisions, because they would be around to observe the progress and fruits of their decisions. Therefore, the CEOs are likely to be proactive and magnanimous in their decisions because of such a psychological influence (Kyereboah-Coleman, 2007). Thus, the CEO's tenure is a significant moderator. On the other hand, the longer a CEO runs an SME, the more likely they are to become lax and seek to amass more power and control, hence leading to empire-building to the detriment of the business' welfare. This confirms the leader life cycle theory proposed by Hambrick and Fukutomi (1991), which asserts that performance slumps as CEOs' interest in tasks gradually decreases, usually after six years on the job (Giambatista, 2004). Therefore, there is a need to discover what tenure is too long or too short in the Ghanaian SME context.

\section{CONCLUSIONS}

This study showed that individual components of governance structures did not influence the performance of SMEs. According to Lam and Lee (2008), CEO duality usually results in CEO dominance, leading to the ineffective monitoring of management, thus defeating the board's purpose. The audit committee was also not found to significantly influence enterprise performance, although the audit committee functions as an additional control mechanism that ensures that shareholders' interests are secured (Ahmed \& Gabor, 2012). The frequency of audit committee's meetings allows it to perform their functions effectively, as they can do concurrent monitoring to safeguard the interest of shareholders. The leadership structure of boards does not directly influence the performance of the enterprise in any way. However, CEO tenure proved to have a significant negative moderating effect on the governance structure-enterprise performance link.

The current study is not without limitations. First is the limited number of governance structure components considered for the study. More components could have been added 
to the model, which could then have yielded a different result and expanded the discourse of the study. Furthermore, instead of employing the simple random sampling technique which is more unbiased - the purposive-snowball sampling technique was used instead. Thus, structural equation modelling (SEM) was not used, which deprived the analysis of rigor. Future studies must focus on how SMEs in Ghana can put CEOs and board succession plans in place so as to ensure sustainable creativity and innovation in enterprises.

\section{REFERENCES}

Abor, J., \& Biekpe, N. (2007). Corporate governance, ownership structure and performance of SMEs in Ghana: implications for financing opportunities. Corporate Governance, 7(3), 288-300.

Abor, J., \& Quartey, P. (2010). Issues in SME development in Ghana and South Africa. International Research Journal of Finance and Economics, 39(6), 215-228.

Agwu, M.O., \& Emeti, C.I. (2014). Issues, challenges, and prospects of small and medium scale enterprises (SMEs) in Port-Harcourt City, Nigeria. European Journal of Sustainable Development, 3(1), 101.

Allgood, S., \& Farrell, K.A. (2000). The effect of CEO tenure on the relation between enterprise performance and turnover. Journal of Financial Research, 23(3), 373-390.

Ansong, A. (2015). Effects of corporate governance on financial performance of small and medium scale enterprises in the Accra metropolis, Ghana (Doctoral dissertation, University of Cape Coast). Retrieved from https://ir.ucc.edu.gh/jspui/bitstream/.../3797/1/ANSONG\%2C\%202015.pdf on January 10, 2015.

Badolato, P.G., Donelson, D.C., \& Ege, M. (2014). Audit committee financial expertise and earnings management: The role of status. Journal of Accounting and Economics, 58(2-3), 208-230.

Bertrand, M., Black, S.E., Jensen, S., \& Lleras-Muney, A. (2019). Breaking the glass ceiling? The effect of board quotas on female labour market outcomes in Norway. The Review of Economic Studies, 86(1), 191-239.

Cadbury, A. (1992). The financial aspects of corporate governance (Cadbury report). London, UK: The Committee on the Financial Aspect of Corporate Governance (The Cadbury Committee and Gee and Co, Ltd). Retrieved from https://ecgi.global/sites/default/files/codes/documents/cadbury.pdf on June 7, 2019.

Coles, J.L., Daniel, N.D., \& Naveen, L. (2008). Boards: Does one size fit all? Journal of Financial Economics, 87(2), 329-356.

De Silva Lokuwaduge, C. (2011). Analysis of governance and performance of Australian universities. In Journal of the World Universities Forum, 4(2), 69-84. Chicago, USA: Common Ground Publishing.

Dess, G.G., \& Robinson, R.B. (1984). Measuring organizational performance in the absence of objective measures: the case of the privately-held enterprise and conglomerate business unit. Strategic Management Journal, 5(3), 265-273.

Elsayed, K. (2007). Does CEO duality really affect corporate performance? Corporate Governance: An International Review, 15(6), 1203-1214.

Emile, R., Ragab, A., \& Kyaw, S. (2014). The Effect of Corporate Governance on Enterprise Performance, Evidence from Egypt. Asian Economic and Financial Review, 4(12), 1865.

Freeman, E. (1984). Strategic Management: A Stakeholder Approach. Boston, MA: Pitman.

Galoji, S.I., Ahmed, F., \& Johari, H. (2013). A moderating effect of leadership tenure on the relationship between leadership self-efficacy and effective leadership behaviour. Jurnal Teknologi, 64(3), 61-67. Retrieved from https://sainshumanika.utm.my/index.php/sainshumanika/article/viewFile/69/69 on June 7, 2019. 
Gibson, K. (2000). The moral basis of stakeholder theory. Journal of Business Ethics, 26, 245-57.

Gill, M., Flynn, R.J., \& Reissing, E. (2005). The governance self-assessment checklist: An instrument for assessing board effectiveness. Nonprofit Management and Leadership, 15(3), 271-294.

Harjoto, M.A., \& Jo, H. (2008). Board leadership and enterprise performance. Journal of International Business and Economics, 8(3), 143-154.

Hambrick, D.C., \& Fukutomi, G.D. (1991). The seasons of a CEO's tenure. Academy of Management Review, 16(4), 719-742.

Hayes, A.F. (2017). Introduction to mediation, moderation, and conditional process analysis: A regression-based approach. New York, USA: Guilford publications. Retrieved from http://afhayes.com/introduction-to-mediation-moderation-and-conditional-process-analysis.html on June 7, 2019.

Johannisson, B., \& Huse, M. (2000). Recruiting outside board members in the small family business: An ideological challenge. Entrepreneurship and Regional Development, 12, 353-378.

Klepczarek, E. (2017). Corporate Governance Theories in the New Institutional Economics Perspective. The Classification of Theoretical Concepts. Studia Prawno-Ekonomiczne, 105, 243-258.

Kumar, N., \& Singh, J.P. (2013). Effect of board size and promoter ownership on enterprise value: some empirical findings from India. Corporate Governance 13(1), 88-98. https://doi.org/10.1108/14720701311302431

Kyereboah-Coleman, A. (2007). The impact of capital structure on the performance of microfinance institutions. The Journal of Risk Finance, 8(1), 56-71.

Kyereboah-Coleman, A., \& Amidu, M. (2008). The link between small business governance and performance: The case of the Ghanaian SME sector. Journal of African Business, 9(1), 121-143.

Kyereboah-Coleman, A., Biekpe, N. (2006). The link between corporate governance and performance of the non-traditional export sector: evidence from Ghana. The International Journal of Business in Society, 6(5), 609-623.

Limbach, P., Schmid, M., \& Scholz, M. (2015). Do CEOs matter? Corporate performance and the CEO life cycle. SSRN Electronic Journal. https://doi.org/10.2139/ssrn.2626340

Luo, X., Kanuri, V.K., \& Andrews, M. (2014). How does CEO tenure matter? The mediating role of enterprise-employee and enterprise-customer relationships. Strategic Management Journal, 35(4), 492-511.

Mayur, M., \& Saravanan, P. (2017). Performance implications of board size, composition and activity: empirical evidence from the Indian banking sector. Corporate Governance: The International Journal of Business in Society, 17(3), 466-489. doi.org/10.1108/CG-03-2016-0058

Merika, A., Triantafyllou, A., Kalogeropoulou, S., \& Kalokairinos, M. (2016). The causal relationship between CEO tenure and enterprise financial performance in the shipping industry, 17(1), 1-25. Paper presented at European Financial Management Association (EFMA) Conference in Basel, Switzerland. Retrieved from https://www.researchgate.net/publication/313250394_The_Causal_Relationship_Between_CEO_Tenure_and_Firm_Financial_Performance_in_the_Shipping_Industry.

Muth, M.M., \& Donaldson, L. (1998). Stewardship theory and board structure: a contingency approach. Corporate Governance, 6(1), 5-28.

NORDEA (2020). Ghana: Economic and Political Overview. Nordea trade. Retrieved from https://www. nordeatrade.com/en/explore-new-market/ghana/economical-context on May 2, 2020.

Nunnally, J.C., \& Bernstein, I.H. (1994). The assessment of reliability. Psychometric Theory, 3(1), 248292.

OECD. (2004). OECD Principles of corporate governance. Paris, OECD. 
Ojeka, S., Iyoha, F.O., \& Obigbemi, I.F. (2014). Effectiveness of audit committee and firm financial performance in Nigeria: an empirical analysis. Journal of Accounting and Auditing: Research \& Practice, 2014(2014), https://doi.org/10.5171/2014.301176

Okofo-Darteh, D., Amartei-Kwei, A., \& Boahen, S.O. (2020). Perceived leadership styles and SME performance in Ghana: Organizational culture as a mediator? Journal of Academy of Business and Economics, 20(1), 49-66.

Omer, T.C., Shelley, M.K., \& Tice, F.M. (2019). Do director networks matter for financial reporting quality? Evidence from audit committee connectedness and restatements. Management Science, 1-28. https://doi.org/10.1287/mnsc.2019.3331.

Pearce, J.A., Robbins, D.K., \& Robinson, R.B. (1987). The impact of grand strategy and planning formality on financial performance. Strategic Management Journal, 8(2), 125-134.

Pfeffer, J., \& Salancik, G.R. (1978). The External Control of Organisations: A Resource-Dependence Perspective. New York, NY: Harper \& Row.

Pfeffer, J. (1973). Size, composition and function of corporate boards of directors: the organisationenvironment linkage. Administrative Science Quarterly, 18, 349-64.

Ponnu, C.H. (2008). Corporate governance structures and the performance of Malaysian public listed companies. International Review of Business Research Papers, 4(2), 217-230.

Rahman, R.A., \& Haniffa, R.M. (2005). The effect of role duality on corporate performance in Malaysia. Corporate Ownership and Control, 2(2), 40-47.

Rashid, A. (2009, July). Board composition, board leadership structure and firm performance: Evidence from Bangladesh. In Proceedings of the 2009 AFAANZ Conference. Accounting \& Finance Association of Australia and New Zealand.

Sanda, A.U., Mukaila, A.S., \& Garba, T. (2003). Corporate Governance Mechanisms and Firm Financial Performance in Nigeria. Final Report Presented to the Biannual Research Workshop of the AERC, Nairobi, Kenya, 24-29.

Schmid, M.M., \& Zimmermann, H. (2005). Should chairman and CEO be separated? Leadership structure and enterprise performance in Switzerland SSRN eLibrary.

Sonmez, M., \& Yildirim S. (2015). A Theoretical Aspect on Corporate Governance and Its Fundamental Problems: Is It a Cure or Another Problem in the Financial Markets?. Journal of Business Law and Ethics, 20-35.

Tabachnick, B.G., Fidell, L.S., \& Ullman, J.B. (2007). Using multivariate statistics (5th ed, pp. 481-498). Boston, MA: Pearson.

Topak, M.S. (2011). The effect of board size on firm performance: Evidence from Turkey. Middle Eastern Finance and Economics, 14(1), 1450-2889.

Tornyeva, K., \& Wereko, T. (2012). Corporate governance and enterprise performance: Evidence from the insurance sector of Ghana. European Journal of Business and Management, 4(12), 95-112.

Venkatraman, N., \& Ramanujam, V. (1987). Measurement of business performance in strategy research: A comparison of approaches. Academy of Management Review, 11(4), 801-814.

Yeh, Y.H., Lee, T.S., \& Ko, C.E. (2002). Corporate governance and rating system. Taipei, Taiwan: Sunbright Culture Company. 


\section{Appendix:}

Governance structure variables - the presence of an audit committee, board size adequacy, and board leadership - were computed as the mean of aggregate responses to question items relating to each governance structure component. Governance structure was also operationalised as the mean scores index of computed governance structure components. Enterprise performance was computed as the mean of the aggregate of responses to the four question items on the enterprise performance survey. Therefore, enterprise performance in this study is defined as the composite index of perceptions of profitability, sales, market share, and productivity. 


\section{Authors}

Daniel Okofo-Darteh Jr conceived the concept of the study, conducted the data analysis, and prepared the manuscript, while Emmanuel Selase Asamoah critically reviewed the literature, proofread, and reviewed the manuscript for submission.

\section{Daniel Okofo-Darteh Jr}

MPhil in Leadership (the University of Professional Studies Accra, Ghana). His research interests include higher education management, small and medium-sized business performance, leadership in organizations, and public sector business management.

Correspondence to: Daniel Okofo-Darteh Jr, the University of Professional Studies Accra, Faculty of Management Studies, Department of Business Administration, P.O. Box LG 149, Accra, Ghana, e-mail: daniel.okofo-darteh@upsamail.edu.gh

ORCID ㄴ) http://orcid.org/0000-0003-4524-3578

\section{Emmanuel Selase Asamoah}

PhD in Economics and Management (Tomas Bata University, Zlín). His research interest lies in the area of business competitiveness and performance.

Correspondence to: Emmanuel Selase Asamoah, the University of Professional Studies Accra, Faculty of Management Studies, Department of Business Administration, P.O. Box LG 149, Accra, Ghana, e-mail: emmanuel.asamoah@upsamail.edu.gh

ORCID (1) https://orcid.org/0000-0002-6200-4563

\section{Copyright and License}



This article is published under the terms of the Creative Commons

Attribution - NoDerivs (CC BY-ND 4.0) License

http://creativecommons.org/licenses/by-nd/4.0/

Published by Cracow University of Economics - Krakow, Poland

The copyediting and proofreading of articles in English is financed in the framework and Higher Education of contract No. 913/P-DUN/2019 by the Ministry of Science and Higher Education Republic of Poland of the Republic of Poland committed to activities aimed at science promotion. 
